\title{
PENGARUH PEMBERIAN SARI KURMA TERHADAP PENINGKATAN KADAR HEMOGLOBIN PADA REMAJA PUTRI YANG MENGALAMI ANEMIA
}

\section{EFFECT OF DATE JUICE ON THE IMPROVEMENT OF HEMOGLOBIN LEVELS IN TEENAGE GIRLS WITH ANEMIA}

\author{
Sofia Mawaddah ${ }^{1}$, Vopy $^{2}$ \\ ${ }_{1 \star^{2}}$ Jurusan Kebidanan Poltekkes Kemenkes Palangka Raya, Indonesia \\ E-mail: sofizline@gmail.com
}

\begin{abstract}
ABSTRAK
Anemia pada remaja dapat menyebabkan keterlambatan pertembuhn fisik, gangguan perilaku serta emosional. Beberapa faktor penyebab anemia yaitu rendahnya asupan zat besi dan zat gizi lainnya seperti vitamin A,C,Folat, Riboplafin dab B12. Tujuan penelitian ini adalah untuk mengetahui pengaruh sari kurma terhadap peningkatan kadar hemoglobin pada remaja putri. Metode penelitian yang digunakan quasi eksperimen, dengan pendekatan One group pretestpostettest design. Teknik sampel dengan Consecutive sampling sebanyak 35 sample remaja putri dengan variabel independen sari kurma, variabel dependen kadar hemoglobin, dan variabel luar usia, pendidikan orang tua, pendapatan orang tua dan kebiasaan sarapan pagi. Analisis univariat menggunakan distribusi, frenkuesi, dan persentasi. Analisa bivariat menggunakan uji paired sample t-test. Hasil uji paired sample t-test menunjukan ada pengaruh sari kurma terhadap peningkatan kadar hemoglobin pada remaja putri di SMPN 11 Palangka Raya dengan $p$-Value $=0,00$. Sari kurma dapat digunakan sebagai salah satu alternative pilihan untuk meningkatkan kadar $\mathrm{Hb}$ pada remaja puteri.
\end{abstract}

Kata Kunci : Anemia, Hemoglobin, Sari kurma, Remaja putri

\begin{abstract}
Anemia in adolescents can cause delay in physical recovery, behavioral and emotional disorders. Some of the factors that cause anemia are low intake of iron and other nutrients such as vitamins A, C, Folate, Riboplafin and B12. The purpose of this study was to determine the effect of date juice on increasing hemoglobin levels in young women. The research method used was quasi-experimental, with the one group pretest-posttest design approach. Sampling technique with consecutive sampling as many as 35 samples of young women with independent date juice, the dependent variable hemoglobin levels, and variables outside of age, parental education, parental income and breakfast habits. Univariate analysis uses distribution, frequency, and percentage. Bivariate analysis using paired sample t-test. Paired sample t-test test results. Shows there is an effect of date juice on increasing hemoglobin levels in young women at SMPN 11 Palangka Raya with $p$-value $=0.00$. Date palm juice can be used as an alternative choice for increasing $\mathrm{Hb}$ levels in adolescent girls.
\end{abstract}

Keywords: Anemia, Date Juice, Hemoglobin, Teenage girls 


\section{PENDAHULUAN}

Anemia adalah keadaan saat jumlah sel darah merah atau jumlah hemoglobin dalam sel darah merah berada di bawah normal. Sel darah merah mengandung hemoglobin yang memungkinkan mengangkut oksigen dari jantung yang diperoleh idari paru-paru dan mengantarkannya ke seluruh bagian tubuh. Penyebab anemia yang paling sering adalah perdarahan yang berlebihan, rusaknya sel darah merah secara berlebihan atau kekurangan pemebentukan sel darah merah (Hematopoiesis yang tidak efektif). ${ }^{1}$

Anemia adalah penyakit darah yang sering ditemukan terutama pada remaja putri, kadar $\mathrm{Hb}$ normal pada remaja putri adalah $12 \mathrm{gr} / \mathrm{dl}$. Remaja putri dikatakan anemia jika kadar Hbnya kurang dari 12 gr/dl. Remaja putri lebih rentan terkena anemia dibandingkan dengan remaja laki-laki karena kebutuhan zat besi pada remaja putri adalah 3 kali lebih besar dari pada laki-laki, remaja putri setiap bulannya mengalami menstruasi dimana kehilangan zat besi $\pm 1,3 \mathrm{mg} /$ hari. $^{2}$

Secara umum tingginya prevalensi anemia disebabkan oleh rendahnya asupan zat besi dan zat gizi lainnya seperti vitamin A,C,Folat, Riboplafin dab B12. Kebutuhan zat besi dalam seharinya dpat dipenuhi dengan mengkonsumsi sumber makanan hewani sebagai salah satu sumber zat besi yng mudah diserap, mengkonsumsi sumber makanan nabati yng merupakan sumber zat besi yang tinggi tetapi sulit diserap. $^{3}$

Anemia pada remaja dapat menyebabkan keterlambatan pertumbuhan fisik, gangguan perilaku serta emosional. Hal ini dapat mempengaruhi proses pertumbuhan dan perkembangan sel otak sehingga daya tahan tubuh menurun, mudah lemas, mudah meras lapar, konsentrasi belajar terganggu serta produktifitas kerja yang rendah.
Sari kurma adalah minuman herbal yang bersal dari buah kurma yang mengandung protein, lemak, minerl, zat besi dn zat asam. Buah kurma sangat kaya akan serat dan sumber kalium yang sangat baik sekali. Dalam 5 butir buah kurma \pm mengandung zat 115 kalori dan zat besi $1,2 \mathrm{mg}$ yang dapat membantu meningkatkan kadar hemoglobin dan mencegah anemia. ${ }^{5}$

Berdasarkan uraian tersebut, maka peneliti tertarik utnuk meneliti "Pengaruh Pemberian Sari Kurma Terhadap Peningkatan Kdr Hb Pada Remaja Putri"

\section{METODE PENELITIAN}

Penelitian ini menggunakan Quasy Eksperimen dengn desain penelitian One Grup Pretest-Posttest. Pengambilan sampel penelitian ini menggunakan Consecutive Sampling yaitu suatu teknik pengambilan sampel dengan memilih sampel yang memenuhi kriteria penelitian untuk tujuan tertentu hingga jumlah sampel terpenuhi. ${ }^{6}$ Penelitian ini dilakukan di SMP Negeri 11 Palangka Raya pada bulan Januari 2019.

Populasi pada penelitian ini yaitu remaja putri di SMPN 11 Palangka Raya. Sampel pada penelitian ini adalah remaja putri yang mengalami anemia berjumlah 35 responden. Kriteria insklusi dalam penelitian ini yaitu responden dapat berkomunikasi dengan baik, yang mengalami anemia, tidak memiliki riwayat penyakit ginjal, malaria dan tuberkulosis. Kriteria eksklusi dalam penelitian ini yaitu responden berpuasa saat pengambilan darh, sakit saat pengambilan data dan tidak mengalami anemia.

Teknik pengumpulan data pada penelitian ini yaitu peneliti melakukan wawancara dengan responden menanyakan identitas responden dan 
menanyakan apakah pernah melakukan pemeriksaan $\mathrm{Hb}$ sebelumnya, peneliti menjelaskan bagaimana prosedur penelitian ini dilakukan, setelah dilakukan informed consent, peneliti akan melakukan pemeriksaan $\mathrm{Hb}$ responden alat yang digunakan peneliti yaitu Hemometer digital. Jika setelah dilakukan pemeriksaan dan ada terdapat remaja putri yang anemia, maka peneliti akan memberikan intervensi yaitu diberikan sari kurma dlam kemasan botol 360 gram diminum $2 \times 1$ sendok makan pada pagi setelah makan dan malam hari sebelum tidur.

Responden mengkonsumsi sari kurma selama 2 minggu dan pada hari ke 14 kadar $\mathrm{Hb}$ remaja putri diperiksa kembali menggunakan alat Hemometer digital apakah terjadi peningkatan kad $\mathrm{Hb}$ setelah remaja putri mengkonsumsi sari kurma selama 2 minggu. Analisis data pada penelitian ini yaitu analisis univariat dan analisis bivariat dengan Uji -Paired Sample T-test untuk menguji pengaruh pemberian sari kurma terhadap peningkatan kadar $\mathrm{Hb}$ pada remaja putri.

\section{HASIL}

Tabel 1. Distribusi Responden Penelitian

\begin{tabular}{lcc}
\hline Variabel & $\begin{array}{c}\text { Frekuensi } \\
(\mathrm{n})\end{array}$ & $\begin{array}{c}\text { Persentase } \\
(\%)\end{array}$ \\
\hline Umur & & \\
12 tahun & 16 & 45,7 \\
13 tahun & 16 & 45,7 \\
14 tahun & 3 & 8,6 \\
Total & 35 & 100 \\
\hline Kebiasaan & & \\
Sarapan & 13 & 37,1 \\
Pagi & 22 & 62,9 \\
Ya & & \\
Tidak & & \\
Total & 35 & 100 \\
\hline
\end{tabular}

Berdasarkan tabel 1 diketahui remaja yang berumur 12 tahun ada 16 responden $(45,7 \%), 13$ tahun ada 16 responden $(45,7 \%)$ dan 14 tahun ada 3 responden
(8,6\%). Pada tabel 1 juga diketahui 13 responden yang biasa sarapan pagi $(37,1 \%)$ dan 22 responden yang tidak biasa sarapan pagi $(62,9 \%)$.

Tabel 2. Rata-rata Kada Hb Remaja Putri Sebelum dan Sesudah Konsumsi Sari Kurma

\begin{tabular}{lcccc}
\hline Variabel & Mean & SD & SE & $\mathrm{n}$ \\
\hline $\begin{array}{l}\mathrm{Hb} \\
\text { sebelum } \\
\text { diberikan }\end{array}$ & 10,9 & 0,496 & 0,838 & 35 \\
sari kurma & & & & \\
\hline $\mathrm{Hb}$ & 11,9 & 0,418 & 0,706 & 35 \\
$\begin{array}{l}\text { sesudah } \\
\text { diberikan }\end{array}$ & & & & \\
sari kurma & & & & \\
\hline
\end{tabular}

Berdasarkan tabel 2 diketahui dari 35 remaja putri, rata-rata kadar $\mathrm{Hb}$ remaja putri sebelum diberikan sari kurma 10,9 gr/dl. Pada tabel 2 juga diketahui dari 35 remaja putri, rata-rata kadar $\mathrm{Hb}$ remaja putri sesudah diberikan sari kurma 11,9 gr/dl.

\begin{tabular}{lcccc} 
Tabel 3. Perbedaan Kadar Hb Remaja & \multicolumn{2}{c}{$\begin{array}{c}\text { Sebelum } \\
\text { San }\end{array}$} & $\begin{array}{c}\text { Sesudah } \\
\text { dan }\end{array}$ \\
$\begin{array}{l}\text { Pemberian Sari Kurma } \\
\text { Variabel }\end{array}$ & Mean & SD & SE & $\begin{array}{c}\text { p- } \\
\text { Value }\end{array}$ \\
\hline Sebelum &,- 9771 & 0,327 & 0,553 & 0,00 \\
- & & & & \\
Sesudah & & & & \\
\hline
\end{tabular}

Berdasarkan tabel 3 didapatkan ratarata kadar $\mathrm{Hb}$ remaja putri sebelum dan sesudah diberikan sari kurma mengalami peningkatan yaitu 0,9771 dengan standar deviasi 0,327 dan standar error 0,553. Berdasarkan tabel 3 juga diketahui hasil uji statistik yaitu didapatkan nilai $p$-Value $0,00(>0,005)$. Maka dapat disimpulkan, ada perbedaan yang signifikan antara kadar $\mathrm{Hb}$ remaja putri sebelum dan sesudah diberikan sari kurma.

\section{PEMBAHASAN}

Hasil penelitian menunjukkan nilai rata-rata kadar $\mathrm{Hb}$ remaja putri mengalami 
peningkatan sesudah diberikan sari kurma. Hasil penelitian Wiulin Setiowati pada tahun 2016 menyatakan bahwa responden yang diberikan sari kurma sebagian besar mengalami peningkatan kadar $\mathrm{Hb}^{7}$ Hasil penelitian Noor Cholifah pada tahun 2017 juga menyatakan ada pengaruh pemberian sari kurma terhadap kada $\mathrm{Hb}$ remaja putri yang mengalami anemia di SMK Raden Umar Said Kudus. ${ }^{8}$ Penelitian Diyah Ayu Susilowati pada tahun 2017 juga menyatakan ada pengaruh sari kurma pada kadar $\mathrm{Hb}$ remaja putri yang mengalami anemia di SMA 2 Yogyakarta. ${ }^{9}$

Remaja putri dikatakan anemia jika kadar $\mathrm{Hb}<12 \mathrm{gr} / \mathrm{dl}$, remaja putri lebih rentan mengalami anemia dibandingkan remaja laki-laki. Remaja putri setiap bulannya mengalami menstruasi yang menyebabkan remaja putri kehilangan darah, itu sebabnya kebutuhan zat besi pada remaja putri 3 kali lebih besar dari remaja laki-laki untuk mengembalikan kondisi tubuhnya ke keadaan semula sebelum remaja putri mengalami menstruasi. ${ }^{10}$

Anemia dapat terjadi karena berkurangnya penyediaan besi untuk eritropoesis sehingga pada akhirnya pembentukan kadar $\mathrm{Hb}$ berkurang. Anemia adalah suatu keadaan dimana jumlah sel darah merat ata $\mathrm{Hb}$ kurang dari normal. Kadar $\mathrm{Hb}$ normal pada remaja putri adalah 12-16 gr/dl, kadar $\mathrm{Hb}$ normal pada remaja lakilaki yaitu 14-18gr/dl. ${ }^{11}$

Ada beberapa faktor yang mendukung remaja putri mengalai anemia yaitu adanya penyakit infeksi yang kronis, menstruasi yang berlebihan, perdarahan yang mendadak seperti kecelakaan dan jumlah makanan atau penyerepan diet yang buruk. Dampak anemia pada remaja putri antara lain menurunnya kesehatan reproduksi, terhambatnya perkembangan motorik, mental dan kecerdasan, menurunkn kemampuan dan konsentrasi belajar, menurunkan fisik olahraga serta tingkat kebugaran dan muka pucat. ${ }^{12}$
Sari kurma adalah herbal yang berasal dari buah kurma, manfaat dari buah kurma bagi kesehatan tubuh karena buah buah mengandung zat gula sederhana yaitu zat fruktosa dan dekstrosa. Zat-zat tersebut sangat mudah dicerna dan dapat mengisi energi tubuh. Kandungan lain dari buah kurma yaitu protein, lemak, mineral, sumber kalium, zat besi dan zat asam folat. Dalam 5 butir buah kurma dengan berat \pm 45 gram mengandung zat kalori sebanyak 115 dan zat karbohidrat. Buah kurma mengandung mineral yaitu asam folic 5,4 mikrog, mineral kalsium 52 mg, magnesium $50 \mathrm{mg}$, tembaga $2,4 \mathrm{mg}$, sulfur $14,7 \mathrm{mg}$, besi $1,2 \mathrm{mg}$, zink $1,2 \mathrm{mg}$, fosfor $63 \mathrm{mg}$, energi $323 / 100$ gram, selain mengandung mineral buah kurna juga mengandung unsur yaitu karbohidrat 75 gram, fiber/serat 2,4 gram, protein 2,35 gram, lemak 0,43 gram, vitamin A $90 \mathrm{mg}$, vitamin B1 $93 \mathrm{mg}$, vitamin B2 $144 \mathrm{mg}$, vitamin C 6,1 mg, asam nikonat 2,2 mg. ${ }^{13}$

Hasil uji statistik pada penelitian ini didapatkan nila p-Value 0,000 $(<0,005)$, hal ini menunjukkan ada hubungan pemberian sari kurma terhadap kadar $\mathrm{Hb}$ remaja putri yang mengalami anemia, jadi kadar $\mathrm{Hb}$ remaja putri mengalami peningkatan sesudah diberikan sari kurma.

\section{SIMPULAN DAN SARAN}

Sari kurma dapat digunakan sebagai salah satu alternative pilihan bagi remaja puteri untuk memenuhi kebutuhan zat besi dengan mengkonsumsi secara rutin agar peningkatan kadar $\mathrm{Hb}$ dapat meningkat dengan baik.

Saran bagi peneliti selanjutnya agar dapat mengembangkan penelitian ini dengan meneliti produk dari kurma selain sari kurma.

\section{UCAPAN TERIMA KASIH}

Peneliti sangat berterima kasih kepada Kepala sekolah SMP Negeri 11 Palangka 
Raya yang sudah memberikan izin kepada peneliti untuk melakukan penelitian. Peneliti juga berterima kasih kepada remaja putri di SMP Negeri 11 Palangka Raya yang bersedia menjadi responden penelitian ini.

\section{DAFTAR PUSTAKA}

1. Bakta, I.Anemia Defisiensis Besi. Jakarta: FKUI; 2017.

2. Biawan.Anemia Masalah Gizi Pada Remaja. Jakarta: EGC; 2018.

3. Departemen Kesehatan RI.Survei Demografi Kesehatan Indonesia Tahun 2015. Jakarta: Depkes RI; 2016.

4. Sayogo S. Gizi dan Pertumbuhan Remaja. Jakarta: Fakultas Kedokteran Universitas Indonesia; 2016.

5. Satuhu. Kurma Khasiat dan Olahannya. Jakarta: Penebar Swadaya; 2016.

6. Notoatmodjo S. Metodologi Penelitian Kesehatan. Jakarta: Rineka Cipta; 2016.

7. Setiowati, Wiulin. Faktor-Faktor Yang Mempengaruhi Anemia Pada Remaja. [skripsi]. Surabaya: Buletin Penelitian Kesehatan; 2016.

8. Cholifah, Noor. Pengaruh Pemberian Buah Kurma Pada Remaja Putri di SMK Raden Umar Said Kudus. [skripsi]. Jakarta: Universitas Indonesia; 2017.

9. Susilowati, Diah.Pengaruh konsumsi kurma pada remaja putri di SMA 2 Yogyakarta.[skripsi]. Yogyakarta: Universitas Aisyiyah; 2017.

10. Bumbata.Tips Anemia Tanda Gejala Kekurangan Zat Besi Pada Remaja.Jakarta:EGC;2016

11. Proverawati. Anemia. Bandung: Alfabeta;2017.

12. Merryana. Pengantar Gizi Masyarakat. Jakarta:Kencana; 2017.

13. Yamin.Kandungan Ekstrak Buah Kurma Terhadap Anemia. Yogyakarta: Pustaka Pelajar; 2018 